\title{
IMPLEMENTATION OF LABORATORY MEASUREMENT OF AIRBORNE SOUND INSULATION BASED ON ISO AND ASTM STANDARDS IN NATIONAL STANDARDIZATION AGENCY OF INDONESIA (BSN)

\author{
Implementasi Pengukuran Laboratorium Insulasi Bunyi Medium Udara Mengacu Pada \\ Standar ISO dan ASTM di Badan Standardisasi Nasional (BSN)
}

\author{
Bondan Dwisetyo ${ }^{1}$, Maharani Ratna Palupi ${ }^{2}$, Fajar Budi Utomo ${ }^{3}$, Chery Chaen Putri ${ }^{4}$, \\ Dodi Rusjadi ${ }^{5}$, Ninuk Ragil Prasasti ${ }^{6}$ dan Denny Hermawanto ${ }^{7}$
}

Pusat Riset dan Pengembangan Sumber Daya Manusia, Badan Standardisasi Nasional Komplek Puspiptek Gedung 435, Tangerang Selatan, Indonesia

e-mail: bondan@bsn.go.id

Diterima: 14 April 2020, Direvisi: 4 Agustus 2020, Disetujui: 26 Maret 2021

\begin{abstract}
The implementation of laboratory measurement of airborne sound insulation based on ISO and ASTM standards was carried out at SNSU BSN. The aim of this work to realize the measurement of airborne sound insulation for several sample tests, where the procedure of the test is performed according to the updated standard ISO 10140 and ASTM E90. Besides, the single number rating also is determined based on ISO 717-1 and ASTM E413. This measurement has been conducted in the two reverberation rooms using pressure method consist of measuring the sound pressure level, measuring the reverberation time, obtaining the sound reduction index $(R)$ or sound transmission loss (STL), and determination of a single-number ratings of the samples test. From the results, some parameter requirements such as the frequency range and the rounding procedure of $\mathrm{R}$ or STL influence the measurement result slightly. Subsequently, the significant difference is obtained for the determination of single number rating in the shifting procedure of the reference curve.
\end{abstract}

Keywords: sound insulation, ISO, ASTM, sound reduction index, single number rating

\section{Abstrak}

Telah dilakukan pengukuran laboratorium airborne sound insulation mengacu pada standar ISO dan ASTM di laboratorium Deputi Standar Nasional Satuan Ukuran, Badan Standardisasi Nasional (BSN) oleh kelompok penelitian akustik dan vibrasi. Penelitian ini bertujuan untuk merealisasikan pengukuran airborne sound insulation untuk beberapa sampel uji dimana prosedur pengukuran mengacu pada ISO 10140 dan ASTM E90. Sebagai tambahan, nilai rating tunggal juga ditentukan yang mengacu pada ISO 717-1 and ASTM E413 Dalam penelitian ini, pengukuran dilakukan menggunakan pressure method, dan terdiri beberapa tahapan, diantaranya pengukuran tingkat tekanan bunyi pada kedua ruangan reverberasi, pengukuran waktu dengung di ruang penerima, perhitungan sound reduction index $(R)$ atau sound transmission loss (ASTM), dan penentuan nilai rating tunggal. Dari hasil pengukuran, beberapa parameter yang dipersyaratkan seperti rentang frekuensi dan prosedur pembulatan $R$ atau STL mempengaruhi hasil pengukuran secara halus. Selanjutnya, perbedaan signifikan pada kedua standar tersebut ditemukan pada prosedur penentunan nilai rating tunggal menggunakan kurva referensi pada setiap frekuensi.

Kata kunci: sound insulation, ISO, ASTM, sound reduction index, single number rating

\section{INTRODUCTION}

The sound barrier materials such as masonry, earthwork, steel, concrete, wood, plastics, insulating wool, or composites, which have an important role to control noise between the two rooms, have been utilized widely in an occupancy area such as office, hotel, hospital, meeting room, and other ordinary rooms ( $\mathrm{Fu}$, Chen, Yu, Zhu, \& Zhao, 2019). To ensure and verify the capability of these materials to minimize this unwanted sound between the rooms, therefore, it is necessary to be conducted a test serially that conform to the recognized standard (Kanteyan, Utami, Prasetiyo, \& Yanti, 2018). Furthermore, there are the international standards that regulate the procedure of testing for these products, and it includes the test sample requirements, installation guiding, system of measurement, facilities, and determination of ratings, and the following are ISO (International Organization for Standardization) and ASTM (American Society of Testing and Materials), where these standards 
commonly have been adopted by many institutions. The former is commonly used for European and some Asia nations products, whilst the latter is applicable based on North American standards. Also, both standards have been updated, especially for the test sample mounting procedure, measurement method, and determination of single number rating, where these are not practiced yet in Indonesia, and some laboratory testing still adopt the withdrawn versions (Holler, 2018). Hence, it is necessary to be conducted a test system and facility that refer to these standards (Holler, 2018).

Hereinafter, as the national institutions that implement a standardization, research activity, and service for acoustics and vibration in Indonesia, the National Standardization Agency of Indonesia (BSN) have the facilities and a capability to provide the sound insulation measurement of building materials and building elements that refer to the two aforementioned standards, where the result of this measurement is considered to decide the quality of the specimens for the building insulation purpose (Tsirigoti, Giarma, \& Tsikaloudaki, 2020).

Therefore, this work aims to implement the measurement of airborne sound insulation in the laboratory, where the procedure of the test is performed according to the updated version of ISO 10140 and ASTM E90. The single number rating of these products also is determined in this work based on ISO 717-1 and ASTM E413. The test sample used in this work consist of a single panel (concrete with $150 \mathrm{~mm}$ of thickness), and a sandwich panel composed of zinc alum on the outer side, and rock wool with $50 \mathrm{~mm}$ of thickness in the inner side.

\section{BASIC THEORY}

In principle, sound insulation is the controlling of a room to noise source generated from another room (Wen, Wang, \& Ma, 2019). Moreover, there are two types of sound insulation that commonly have been implemented, and it consists of airborne sound insulation and impact sound insulation (Elsaeed, Naguib, El Mekawy, Ghaly, \& Abu Aly, 2019). The former is the insulation against sound that propagates by air such as traffic noise (Lloret, Duvigneau, Gabbert, \& Rottengruber, 2019). Meanwhile, the latter is the insulation against sound that arises by direct contact of an object on the building element, such as the impact of rain on glazing (Lloret, Duvigneau, Gabbert, \& Rottengruber, 2019). Therefore, figure 1 illustrates these types of sound insulation through two separate rooms, and it depends on the frequency of the sound source.
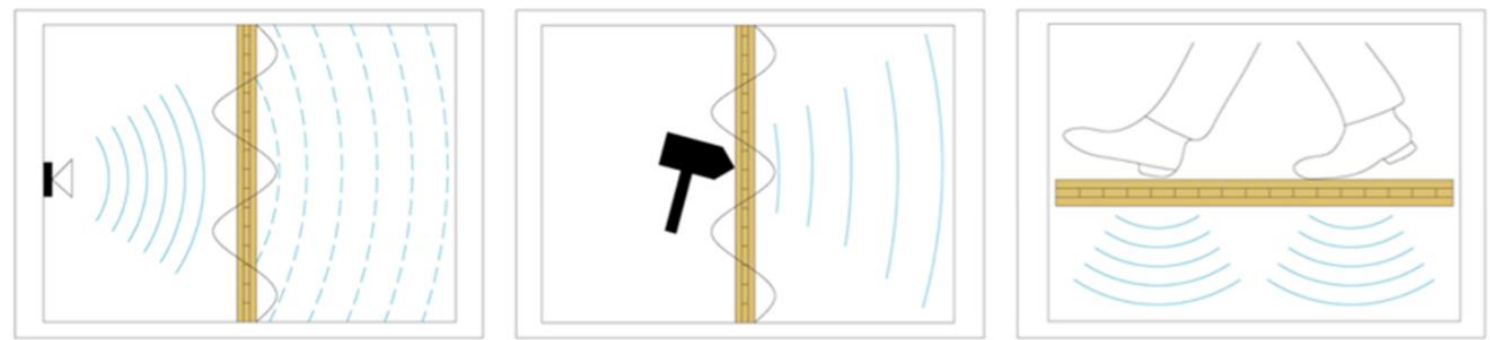

Figure 1 The illustration of sound insulation: airborne sound insulation (left), structure borne and or impact sound insulation (middle and right) (The image of the rash Soundproof Expert Picture, n.d.)

In this work, the airborne sound insulation will be discussed further, because it has been applied widely either in laboratory or field measurement, and, moreover, the façades mainly are liable to airborne sound (Lloret, Duvigneau, Gabbert, \& Rottengruber, 2019).

Sound reduction index $(R)$ or sound transmission loss (STL) can be determined using equation as follows (ISO, 2010) (ASTM, 2016):

$$
R=\overline{L_{1}}-\overline{L_{2}}+10 \log _{A}^{\frac{S}{A}}
$$

$$
S T L=\overline{L_{1}}-\overline{L_{2}}+10 \log \frac{S}{A}
$$

Where,

$\mathrm{L}_{1}=$ the measured SPL in source room (in dB unit)

$\mathrm{L}_{2}=$ the detected SPL from in receiver room (in $\mathrm{dB}$ unit)

For the latest parameter, it can calculated using sabine equation as follows (ISO, 2010) (ASTM, 2016):

$$
A=\frac{0,163 . V}{R T_{\text {Rid }}}
$$


Where,

$\mathrm{V}=$ Volume of receiver room (in $\mathrm{m}^{3}$ )

Afterwards, sound reduction index $(R)$ or sound transmission loss (STL) can be written by equation as follows (ISO, 2010) (ASTM, 2016):

$$
\begin{aligned}
& R=L_{1}-L_{2}+10 \log \frac{S \cdot R T_{\text {tin }}}{0,163 . V} \\
& S T L=L_{1}-L_{2}+10 \log \frac{S \cdot R T_{601}}{0,161 . V}
\end{aligned}
$$

Where, $\mathrm{S}$ and $\mathrm{RT}_{60}$ represent Surface area of the sample test (in $\mathrm{m} 2$ ) and the reverberation time inside receiver room (in second) respectively. In addition, measurement of transmission loss can be implemented using an acoustic impedance tube that will discussed in later (Santoni, Davy, Fausti, \& Bonfligue, 2020), (Granzoto, Scrosati, Scamoni, \&Pian, 2020) .

\section{METHODOLOGY}

Measurement of airborne sound insulation is carried out in two reverberation rooms, and it consists of a source room and a receiver room as mentioned above (Wen, Wang, \& Ma, 2019). The former is the room where the sound pressure level is generated by a sound source. The source used in this work is the white noise source. Whilst the latter is a closed area that obtains the noise from the previous room (Du, 2019). Both of these rooms are separated by a partition with particular compositions, and a test opening, where the specification of these rooms and the test opening is mentioned in ISO 10140-5, meanwhile for the sample test requirements are described in ISO 10140-1.

The measured parameters are sound pressure level (SPL) in the two rooms, and reverberation time (RT60) in the receiver room, where is defined as the time required for the sound source to reduce to a level of $60 \mathrm{~dB}$ when it is turned off inside a closed room (Prato, Casass, \& Schiavi, 2016), and its illustration is shown in figure 2. The procedure of measurement is based on ISO 10140-2, ISO 10140-4, and ASTM E90 - 09.

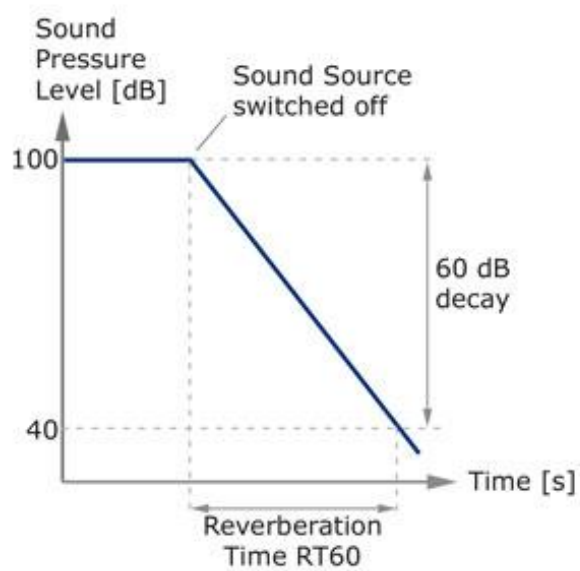

Figure 2 The Illustration of reverberation time.

After measuring these parameters, it is necessary to determine the sound insulation parameter that will be referred to the two standards, where ISO is represented as sound reduction index $(R)$, meanwhile the other is sound transmission loss (STL) that expressed by ASTM for the corresponding frequencies in $\mathrm{dB}$ unit.

Hereinafter, the single number rating is determined according to ISO 717-1 and ASTM E413. Therefore, it is represented as weighted sound reduction index $(\mathrm{Rw})$ for the first standard (ISO, 2013), meanwhile the other is sound transmission class (STC) that given by the second standard (ASTM, 2016), where both of standards are essentially similar. However, there are several differences in the calculation procedure to determine the single number ratings of the two standards.

The first is the measurement of the frequency range, where ISO provides the range from $100 \mathrm{~Hz}$ to $3150 \mathrm{~Hz}$, while $125 \mathrm{~Hz}-4000 \mathrm{~Hz}$ for ASTM (Holler, 2018). After that, the second is the rule of the rounded values among these standards (Holler, 2018). The sound reduction index $(\mathrm{Rw})$ as the ISO product is rounded to the nearest $0.1 \mathrm{~dB}$, meanwhile for the sound transmission loss (STL) of ASTM rounded to the nearest $1 \mathrm{~dB}$ at the corresponding frequency range (Holler, 2018).

Subsequently, the third diversity between both is the rule of reference values shifting (Holler, 2018). The former requires the reference contour at corresponding frequencies is shifted in $1 \mathrm{~dB}$, and, therefore, the positive deviation between the reference values and the obtained sound reduction index is calculated (Holler, 
2018). After that, it is repeated until the sum of these different values does not exceed $32 \mathrm{~dB}$ (Holler, 2018). The similarity procedure also is found in another standard. it provides an additional rule, where the difference values between the reference and the obtained sound transmission loss do not exceed $32 \mathrm{~dB}$, and, as long as this difference of all frequencies does not exceed $8 \mathrm{~dB}$ (Holler, 2018).

Afterward, the last difference is an additional parameter called the spectrum adaptation ( $\mathrm{C}$ and $\mathrm{Ctr}$ ) that only found in ISO standard, meanwhile for the other is not available (Holler, 2018). Hence, the above explanation between the rating procedures is summarized in table 1 (Holler, 2018).

Table 1 The differences parameter between ISO and ASTM for airborne sound insulation (Holler, 2018).

\begin{tabular}{lcc}
\hline \multicolumn{1}{c}{ Parameter } & ISO & ASTM \\
\hline $\begin{array}{l}\text { Frequency } \\
\text { range }\end{array}$ & $\begin{array}{c}100 \mathrm{~Hz}- \\
3150 \mathrm{~Hz}\end{array}$ & $\begin{array}{c}125 \mathrm{~Hz}-4000 \\
\mathrm{~Hz}\end{array}$ \\
$\begin{array}{l}\text { Rounded of } \\
\text { digits }\end{array}$ & $\begin{array}{c}\text { R rounded to } \\
0.1 \mathrm{~dB}\end{array}$ & $\begin{array}{c}\text { STL rounded } \\
\text { to } 1 \mathrm{~dB}\end{array}$ \\
$\begin{array}{l}\text { Difference to } \\
\text { reference } \\
\text { values }\end{array}$ & Sum $\leq 32 \mathrm{~dB}$ & $\begin{array}{c}\text { Sum } \leq 32 \mathrm{~dB}, \\
\text { max } \leq 8 \mathrm{~dB}\end{array}$ \\
$\begin{array}{l}\text { Spectrum } \\
\text { adaptations }\end{array}$ & Available & - \\
\hline
\end{tabular}

By understanding these differences, it is convenient to apply the airborne sound insulation measurement to the appropriate product according to its origins, and of course, to accustom the measurement service to the customer needs. Moreover, some manufacturers request to be tested for their product in accordance with these standards at a time, especially when utilizing it in the western country.

\section{Experiment}

For the details, the apparatus measurement and facilities that used in this work are as follow:
1.White noise generator
2.Power amplifier
3.Dodecahedron loudspeaker
4.Free field microphone
5.Modular precision sound analyzer
6. Two reverberation room
7.Sample test 1 (sandwich panel)
8.Sample test 2 (single panel)

\section{Measuring SPL in the reverberation rooms}

In this work, an experiment was set up using the aforementioned apparatus, and the first step is to measure the SPL in the two reverberation rooms as shown in figure 3 .

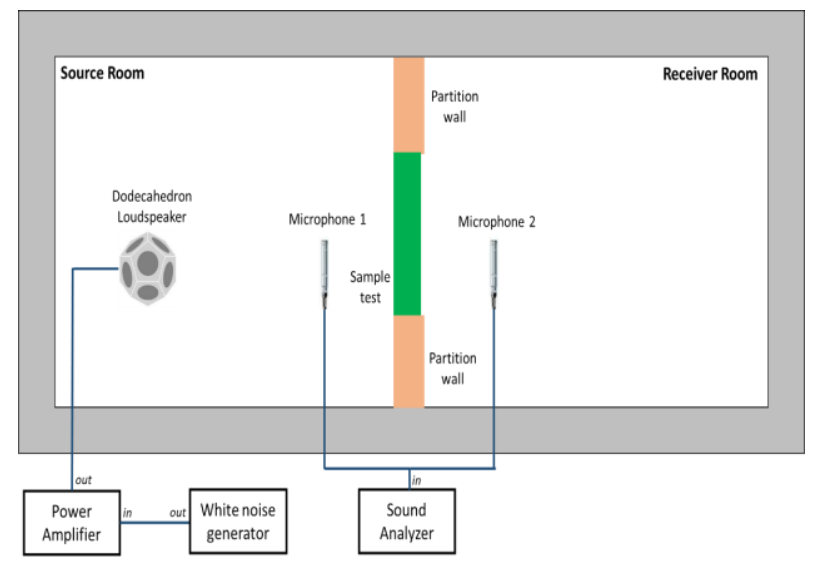

Figure 3a Measurement set up of SPL measurement in two rooms.

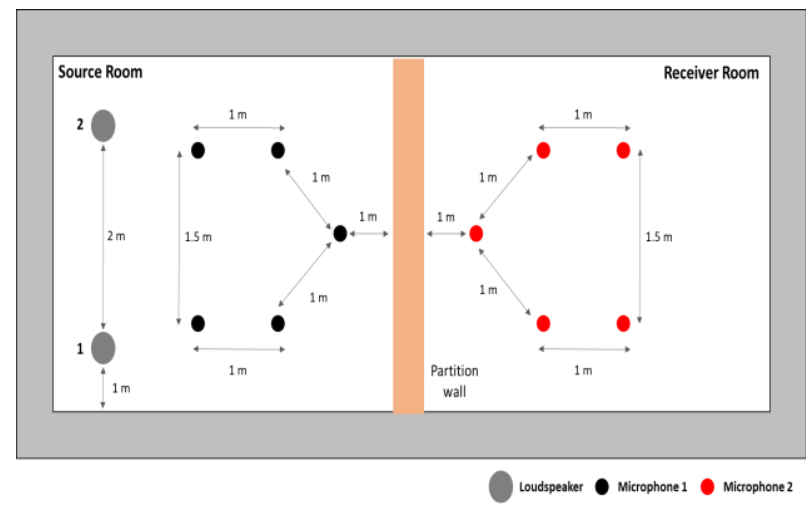

Figure $3 b$ Positions of loudspeaker and microphone on SPL measurement.

According to the ISO, there are some amendments to the type of sound source and its position number in a measurement process. For the old version of ISO, a pink noise source was used to generate SPL within one position, meanwhile a white noise has been utilized at least two positions for the updated standard as seen in figure $3 a$ and figure $3 b$. From these figures, a dodecahedron loudspeaker was placed in the source room, and two of free-field microphone was placed inside the source and receiver room, respectively. Therefore, they were arranged so the distance between this sound source, microphones, and surfaces (walls, floor, and the sample test) as the figure 2 (bottom). After that, the loudspeaker was connected to a power amplifier and a white noise generator, meanwhile, the two microphones were plugged in to sound analyzer in a control room. Afterward, 
by recording the environment parameters in these rooms, and generating the noise from the generator, the SPL was measured by the microphones and indicated on the sound analyzer. For the other loudspeaker and microphone positions, the same steps were also applied.

\section{Measuring $\mathrm{RT}_{60}$ in the receiver room}

The second step is conducted to measure the reverberation time $\left(\mathrm{RT}_{60}\right)$ with the sample test using interrupted noise method inside the receiver room, and it is shown in Figure 4.

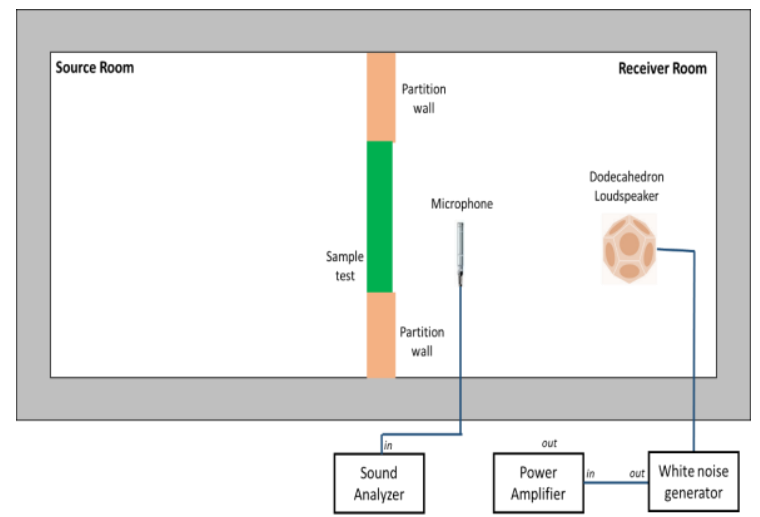

Figure 4 Measurement set up of reverberation with the sample test.

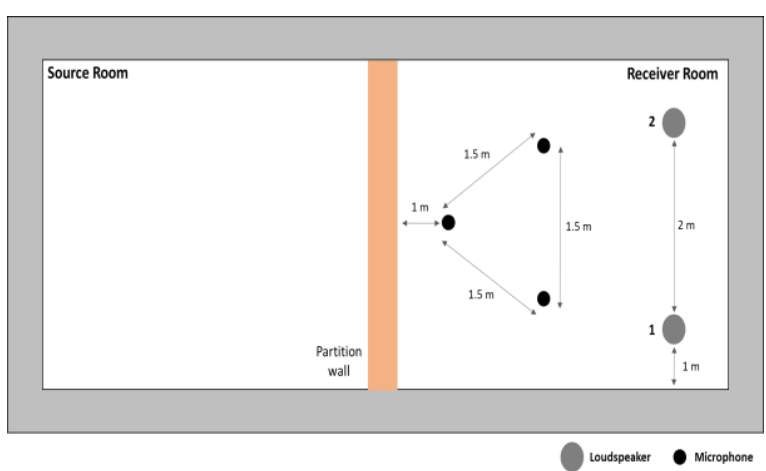

Figure 5 Positions of loudspeaker and microphone on $\mathrm{RT}_{60}$ measurement.

In this step, there is no difference in procedure between the two standards. The dodecahedron loudspeaker was moved to the reverberation room, and a free-field field microphone was placed inside the receiver room. Therefore, they were arranged so the distance between the sound source, microphone, and surfaces (walls, floor, and the sample test) inside this room as the figure 3 (bottom). After that, the loudspeaker was connected to a power amplifier and a white noise generator, meanwhile the microphones were plugged in to sound analyzer in a control room. Afterward, by recording the environment parameters in this room, and generating white noise from the generator at the 5 second, the RT60 was measured and calculated by the sound analyzer directly after the sound source was turned off. For the other loudspeaker and microphone positions, the same steps were also applied.

Finally, after obtaining these measurands, $R_{w}$ and STL were calculated using the equations above. Therefore, the single rating number is determined using the aforecited procedure of the two standards.

\section{RESULT AND DISCUSSION}

The result of $R$ and STL measurement, and the single number ratings determination of sound insulation measurement for the sandwich panel are shown in table 2 and figure 7 respectively.

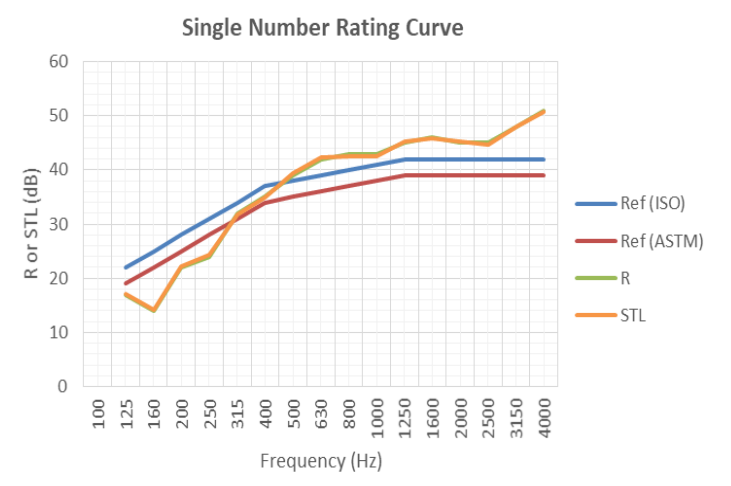

Figure 6 The single number rating curves of the sandwich panel.

From this figure, the curve trend of sound reduction index $(\mathrm{R})$ and sound transmission loss (STC) has the similarity although the two standards have the different requirement of frequency range. The difference values between both are found, where its deviation is small relatively, and moreover, it is influenced by the rounded rule according to the two standards. As mentioned above, the ISO standard provides more detail of $R$ values due to rounding to the nearest $0.1 \mathrm{~dB}$, whilst ASTM requires the rounded to the nearest $1 \mathrm{~dB}$ of STL. Therefore, 
these curves have a tendency to increase within the corresponding frequencies, and it is found that at the frequency of $160 \mathrm{~Hz}, \mathrm{R}$ or STL has the minimum value, where it is affected by the characteristic of the material test. Moreover, the single number ratings that determined based on the two standards have a difference value significantly, where the former has the result is $35 \mathrm{~dB}$ for $\mathrm{Rw}$, meanwhile the later has the rating that its value is $38 \mathrm{~dB}$ for STC. It is affected by the procedure of reference values shifting, where the difference value between the reference and calculation exceeds $8 \mathrm{~dB}$ at the frequency of 160 $\mathrm{Hz}$. Hence, according to ASTM requirements, it is necessary to re-shifting the reference curve after this deviation value is not more than $8 \mathrm{~dB}$.

Table 2 Measurement result of $\mathrm{R}$ and STC of sandwich panel test.

\begin{tabular}{ccccc}
\hline $\begin{array}{c}\mathbf{H} \\
\mathbf{H z}\end{array}$ & $\begin{array}{c}\mathbf{R} \\
\mathbf{d B}\end{array}$ & $\begin{array}{c}\text { STL } \\
\mathbf{d B}\end{array}$ & $\begin{array}{c}\mathbf{R w} \\
\mathbf{d B}\end{array}$ & $\begin{array}{c}\text { STC } \\
\mathbf{d B}\end{array}$ \\
\hline 125 & 19.5 & 20.0 & 35.0 & 38.0 \\
160 & 14.1 & 14.0 & & \\
200 & 22.3 & 22.0 & & \\
315 & 24.0 & 24.0 & & \\
400 & 32.1 & 32.0 & & \\
500 & 34.4 & 34.0 & & \\
630 & 38.3 & 38.0 & & \\
800 & 42.2 & 42.0 & & \\
1000 & 42.3 & 42.0 & & \\
1250 & 42.4 & 42.0 & & \\
1600 & 44.0 & 44.0 & & \\
2000 & 44.5 & 45.0 & & \\
2500 & 44.2 & 44.0 & & \\
3150 & 44.1 & 44.0 & & \\
4000 & 48.7 & 49.0 & & \\
\hline
\end{tabular}

Subsequently, the result of $R$ and STL measurement, and also the single number ratings for the single wall of concrete are shown in table 3 and figure 8 respectively.

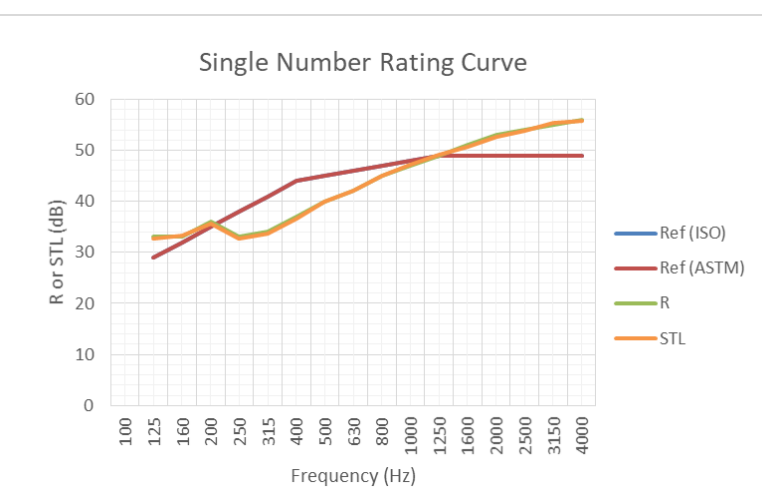

Figure 8 The single number rating curves of the single wall of concrete.

From this figure, the curve trend of sound reduction index $(R)$ and sound transmission loss (STC) has the similarity as well as the previous curves. These curves have a tendency to increase within the corresponding frequencies, where it goes up slightly from the lowest frequency to the frequency of $200 \mathrm{~Hz}$, then, it decreases about $3 \mathrm{~dB}$ to the frequency of 250 $\mathrm{Hz}$. After that, it tends to rise from this frequency to the last frequency. In addition, the difference between both is similar to the first sample test that its value is small relatively, where it is also due to the rounded rule according to the two standards. Therefore, the single number ratings that are determined based on the two standards almost has no deviation, where the difference value between the reference and calculation that exceeds $8 \mathrm{~dB}$ at the corresponding frequency is not found. Hence, it has $s$ the same rating that its value is $45 \mathrm{~dB}$ respectively.

Table 3 Measurement result of R and STC of single wall of concrete.

\begin{tabular}{ccccc}
\hline $\begin{array}{c}\mathbf{F} \\
\mathbf{H z}\end{array}$ & $\begin{array}{c}\mathbf{R} \\
\mathbf{d B}\end{array}$ & $\begin{array}{c}\text { STL } \\
\mathbf{d B}\end{array}$ & $\begin{array}{c}\mathbf{R w} \\
\mathbf{d B}\end{array}$ & $\begin{array}{c}\text { STC } \\
\mathbf{d B}\end{array}$ \\
\hline 125 & 32.3 & 32.0 & 45.0 & 45.0 \\
160 & 32.4 & 32.0 & & \\
200 & 35.0 & 35.0 & & \\
315 & 32.3 & 32.0 & & \\
400 & 34.5 & 35.0 & & \\
500 & 38.0 & 38.0 & & \\
630 & 42.1 & 42.0 & & \\
800 & 44.4 & 44.0 & & \\
1000 & 45.3 & 45.0 & & \\
1250 & 49.2 & 49.0 & & \\
1600 & 51.6 & 52.0 & & \\
2000 & 52.0 & 52.0 & &
\end{tabular}


Implementation Of Laboratory Measurement Of Airborne Sound Insulation Based On Iso And Astm Standards In National Standardization Agency Of Indonesia (BSN)

(Bondan Dwisetyo, Maharani Ratna Palupi, Dodi Rusjadi, Chery Chaen Putri, Fajar Budi Utomo, Ninuk Ragil Prasasti dan Denny Hermawanto)

\begin{tabular}{lll}
\hline \hline 2500 & 54.0 & 54.0 \\
3150 & 55.7 & 56.0 \\
4000 & 56.3 & 56.0 \\
\hline
\end{tabular}

From the results, some parameter such as the frequency range and the procedure of rounding of $R$ and STL does not have a significant deviation on the result of this measurement. However, the significant differences between these standards is found for the single number ratings of the specimen test. The difference of reference values shifting procedure influences the result, and it depends on the characteristic of the sample. When the shifting value procedure is conducted and there are no frequencies that have deviation value exceed $8 \mathrm{~dB}$, the difference is relatively small. However, the condition is vice versa, the difference is significant as the result above.

\section{CONCLUSION}

In this work, the implementation of laboratory measurement of airborne sound insulation for the sample test according to ISO 10140 and ASTM C90 was carried out at The Deputy of National Measurement Standard (SNSU) BSN by Research Group for Acoustics and Vibration. In addition, the single number rating of these products also is determined in this work based on ISO 717-1, and ASTM E413.

From the results, some parameter requirements such as the frequency range and the rounding procedure of the sound reduction index or sound transmission loss determination have an influence the measurement result slightly. Moreover, the significant differences between these standards also is obtained related to the single number ratings of the specimen test in the shifting procedure of the reference curve. It is found, therefore, for the result test of the sandwich panel, where the ISO standard provide the result is $35 \mathrm{~dB}$, meanwhile the ASTM has the rating value is $38 \mathrm{~dB}$. It is affected by the difference value between the reference and calculation exceeds $8 \mathrm{~dB}$ at the frequency of 160 $\mathrm{Hz}$. Hence, according to ASTM requirements, it is necessary to re-shifting the reference curve after this deviation value is not more than $8 \mathrm{~dB}$. Meanwhile, this condition is not found for the other samples. Thus, the deviation of rating value among the standard is not significant. Moreover, this work is necessary to be continued strongly using another method to determine $\mathrm{R}$ or STL, and it should involve the additional of the specimen test to provide the better results.

In addition, these standards can be used as a reference either for the laboratory test or the manufacturer. It is necessary to prepare some equipment and facilities in accordance with the standards depends on the function of the specimen. For a wall and a floor sample, it needs large room without partition, meanwhile for the windows and glazing specimen, a test opening needs to be provided along with the partitions between the rooms.

Even though ASTM has been used more widely in Indonesia, ISO standard provide more information related to the additional parameter for single number rating such as $\mathrm{C}$ and $\mathrm{Ctr}$ that represent quality of the specimen when it utilizes in urban traffic area.

\section{ACKNOWLEDGMENT}

The authors acknowledge the Center for Research and Human Resources Development BSN through the scheme of Internal Research Program on 2020 and 2021.

\section{REFERENCES}

American Society for Testing and Materials. (2016). Classification for Rating Sound Insulation. (ASTM Standard No. E413 16).https://www.astm.org/Standards/E413. htm

American Society for Testing and Materials. (2016). Standard Test Method for Laboratory Measurement of Airborne Sound Transmission Loss of Building Partitions and Elements. (ASTM Standard No.E9016).https://www.astm.org/Standard s/E413.htm

Du, L., Lau, S. K., \& Lee, S. E. (2019). Experimental study on sound transmission loss of plenum windows. The Journal of the Acoustical Society of America, 146(6), EL489-EL495.

EISaeed, A., Naguib, G., El Mekawy, A., \& Ghaly, A. (2019). A PROPOSED USE OF SOUND INSULATION SYSTEMS.

Fu, T., Chen, Z., Yu, H., Zhu, X., \& Zhao, Y. (2019). Sound transmission loss behavior 
of sandwich panel with different truss cores under external mean airflow. Aerospace Science and Technology, 86, 714-723.

Granzoto, N., Scrosati, C., Scamoni, F., \& Piana, E. (2020). Sound reduction index prediction of double-layer gypsum panels through the transfer matrix method. Building Acoustics. 1-27.

Hoeller, C. (2018, December). Review and Comparison of ASTM and ISO Standards on Sound Transmission in Buildings. In INTER-NOISE and NOISE-CON Congress and Conference Proceedings (Vol. 258, No. 5, pp. 23382347). Institute of Noise Control Engineering.

International Organization for Standardization. (2010). Acoustics - Laboratory Measurement of Sound Insulation of Building Elements - Part 2: Measurement of Airborne Sound Insulation. (ISO Standard No. 101402:2010).https://www.iso.org/standard/4208 8.html

International Organization for Standardization. (2010). Acoustics - Laboratory Measurement of Sound Insulation of Building Elements - Part 4: Measurement Procedures and Requirements. (ISO Standard No. 101402:2010).https://www.iso.org/standard/4209 0.html

International Organization for Standardization. (2013). Acoustics - Rating of Sound Insulation in Buildings and of Building Elements - Part 1: Airborne Sound Insulation. (ISO Standard No. 717-
$1: 2013)$.

https://www.iso.org/standard/51968.html

Kanteyan, M. S., Utami, S. S., Prasetiyo, I., \& Yanti, R. J. (2018, August). Sound insulation design improvement for reducing noise of paper factory office. In Journal of Physics: Conference Series (Vol. 1075, No. 1, p. 012060). IOP Publishing.

Lloret, M. G., Duvigneau, F., Gabbert, U., \& Rottengruber, H. (2019). Prediction of the airborne sound transmission through the front end of a vehicle. Automotive and Engine Technology, 4(3), 169-178.

Prato, A., Casassa, F., \& Schiavi, A. (2016). Reverberation time measurements in nondiffuse acoustic field by the modal reverberation time. Applied Acoustics, 110, 160-169.

Santoni, A., Davy, J. W., Fausti, P., \& Bonfligue, P. (2020). A review of the different approaches to predict the sound transmission loss of building partitions. Building Acoustics. 1-27.

Soundproof Expert [image] (n.d.). Retrieve from https://soundproof.expert/how-tosoundproof-existingwall/

Tsirigoti, D., Giarma, C., \& Tsikaloudaki, K. (2020). Indoor Acoustic Comfort Provided by an Innovative Preconstructed Wall Module: Sound Insulation Performance Analysis. Sustainability, 12(20), 8666.

Wen, Z. H., Wang, D. W., \& Ma, L. (2019). Sound transmission loss of sandwich panel with closed octahedral core. Journal of Sandwich Structures \& Materials, 1099636219829369. 